\title{
FORMAÇÃO DO SUJEITO-LEITOR: MODOS DE LER A PARTIR DE ANÚNCIOS PUBLICITÁRIOS EM LIVRO DIDÁTICO
}

\author{
FORMACIÓN DEL SUJETO-LECTOR: MODOS DE LECTURA EN ANUNCIOS PUESTOS EN \\ LIBROS DE TEXTO
}

\section{EDUCATION OF SUBJECT-READER: MODES OF READING ADVERTISEMENTS IN TEXTBOOKS}

\author{
Sandro Braga* \\ Universidade Federal de Santa Catarina \\ Jucirlei Pereira Casagrande** \\ Universidade do Sul de Santa Catarina
}

\begin{abstract}
RESUMO: O presente trabalho tem por objetivo apresentar uma proposta de reflexão acerca dos modos de efetivação da leitura do texto publicitário no livro didático Português Linguagens de William Roberto Cereja e Thereza Cochar Magalhães, do primeiro ano do Ensino Médio e analisar a funcionalidade desses textos na formação do sujeito-leitor, uma vez que a leitura do texto publicitário permite ampliar o repertório do aluno para além do texto puramente verbal, ampliando sobremaneira sua visão discursiva. Além disso, a publicidade faz parte do cotidiano do aluno, é um texto de grande circulação social e, por isso, segundo as orientações da Proposta Curricular de Santa Catarina e dos Parâmetros Curriculares Nacionais, deve fazer parte das aulas de língua portuguesa a fim de um trabalho efetivo de práticas de leitura. A análise pauta-se pelos conceitos da Análise do Discurso de orientação francesa que traz como arcabouço a historicidade na constituição do sujeito, a ideologia como determinante na produção de sentidos e a leitura como o momento crítico da relação entre autor-texto-leitor. Dentro dessa perspectiva de leitura como prática discursiva, entende-se o leitor interpelado pela posição-sujeito; assim, ele (des)constrói o texto lido e atribui-lhe sentidos que nem sempre são os esperados pelo autor. Os resultados apontaram que o livro didático analisado propõe leituras cujo sentido fica circunscrito ao contexto imediato da linguagem verbal, sobretudo, àquele em que o enunciado propicia a avaliação da norma padrão da língua.
\end{abstract}

PALAVRAS-CHAVE: leitura; sentido; texto publicitário; livro didático.

RESUMEN: Este trabajo tiene como objetivo presentar una propuesta de reflexión sobre la producción de la lectura del texto del anuncio en el libro de texto Português Linguagens, William Roberto Cereja y Thereza Cochar Magalhães, para el primer año de proceso escolar y analizar la funcionalidad de estos textos en la formación del sujeto-lector, ya que leer el texto de los anuncios le permite ampliar el repertorio de los estudiantes más allá del texto puramente verbal, ampliando enormemente la competencia discursiva. Además, la publicidad es parte del cotidiano los estudiante, es un texto de gran movimiento social y, por lo tanto, de acuerdo con las directrices de la Propuesta Curricular de Santa Catarina y de los Parámetros Curriculares Nacionales, deben ser parte de las clases de portugués para un trabajo de producción de lectura. El análisis se basa en los conceptos de Análisis del Discurso de orientación francesa como un marco que aporta la historicidad de la constitución del sujeto, la ideología como un factor determinante en la producción de significados y la lectura como el momento crítico de la relación entre autor-texto-lector. Dentro de esta perspectiva la lectura como una práctica discursiva, se entiende al lector interpelado por la posición del sujeto, por lo que construye el texto leído y le asigna direcciones que no siempre son esperadas por el autor. Los resultados mostraron que el análisis del libro de texto sugiere lecturas cuyo significado está restringido al contex to inmediato del lenguaje verbal, especialmente uno en el que el anuncio proporciona la evaluación de la norma estándar del lenguaje.

PALABRAS CLAVE: lectura; sentido; textos publicitarios; libro de texto.

ABSTRACT: The main purpose of this article is to introduce a proposal about a reflection on the ways the reading of advertisements is carried out in the textbook Português Linguagens by William Roberto Cereja and Thereza Cochar Magalhães, which is directed to students in the first high school year. Additionally, it analyzes the functionality of these texts in the education of a reader, since reading the ads allows the student to increase the student's knowledge beyond the purely verbal text, and thus to greatly expand the student's discursive competence. Besides, advertising is part of the student's everyday life, it is a kind of text that presents great social movement and therefore, according to the guidelines of the Curriculum Proposal of Santa Catarina and the National Curriculum Parameters, should be part of Portuguese language classes in order to promote an effective reading practice. The analysis is guided by the concepts of Discourse Analysis of French orientation as a framework that brings the historicity of the constitution of the subject, ideology as a determinant in the production of meanings, and reading as the critical

\footnotetext{
* Doutor em Linguística pela UFSC, professor Adjunto do Departamento de Língua e Literaturas Vernáculas e do Programa de Pós-Graduação em Linguística da UFSC, Coordenador do Laboratório de Leituras e Escritas Acadêmicas (LABEAL). E-mail: sandrocombraga@gmail.com. 
moment of the relationship between author-text-reader. Within this perspective of reading as a discursive practice, the reader is seen as enquired by the subject position, so he/she (de) constructs the text read and then adds to it his/her outputs that are not always anticipated by the author. The results showed that the textbook analyzed proposes readings whose meaning is restricted to the immediate context of verbal language, especially one in which the statement provides the evaluation of the standard norm of the language.

KEYWORDS: reading; meaning; advertising text; textbook.

\section{INTRODUÇÃO}

A leitura é uma prática fundamental na vida de cada indivíduo, uma vez que por meio dela se pode interagir com o mundo, compreendê-lo e, desse modo, posicionar-se criticamente perante a sociedade, sem, necessariamente, se necessitar da presença física do outro.

Pensamos a leitura do ponto de vista discursivo e, por esse viés, ela não implica a existência de um único sentido posto, fechado, mas a compreensão dos diferentes efeitos de sentidos que possam emergir diante de uma materialidade significante. Nesse sentido, o texto não está fechado em si, mas aberto a múltiplas possibilidades de interpretação, embora não sejam quaisquer interpretações. E trabalhar o texto nessa perspectiva pressupõe considerar as diferentes posições do sujeito, as diferentes formações discursivas, a historicidade, uma vez que a Análise do Discurso (doravante AD) leva em conta os processos de produção e o contexto sócio-histórico-cultural como determinantes na produção de sentidos.

Diante disso, a formação de sujeitos-leitores requer um trabalho voltado para além da abstração de sentidos sugeridos. Esse trabalho exige dinamismo entre o texto e as experiências do leitor produzindo, assim, significação. Dessa forma, ao "[...] acolher a compreensão entre seus objetos de reflexão, a AD pode fornecer uma contribuição substancial para o trabalho sobre leitura”. (ORLANDI, 1993, p. 117).

Quando pensamos a leitura em sala de aula, é voz corrente que os alunos têm dificuldades na interpretação de textos, mesmo que esta seja uma interpretação parafrástica que, como afirma Orlandi (1988, p. 12), “[...] se caracteriza pelo reconhecimento (reprodução) de um sentido que se supõe ser o do texto (dado pelo autor)”. E nas práticas de leitura em sala de aula, de acordo com Coscarelli e Cafiero (2002, p. 1),

[…] é possível notar a distância que ainda existe entre essas práticas e as teorias linguísticas, principalmente em relação aos avanços teóricos já alcançados pela Análise do Discurso. São muitos os professores de Ensino Fundamental e Médio que ainda não tiveram contato com as concepções oriundas da $\mathrm{AD} ;[\ldots]$.

A leitura, em uma perspectiva discursiva, vai para além da paráfrase, ela é polissêmica, ou seja, é uma leitura “[...] que se define pela atribuição de múltiplos sentidos ao texto”. (ORLANDI, 1988, p. 12). Ler é, portanto, saber que não há um único sentido, mas que o sentido pode ser outro. E falta ao professor, segundo Coscarelli e Cafiero (2002), esse conhecimento em relação às novas concepções propostas pela AD.

Nesse contexto, entram em cena os livros didáticos, “[...] material no qual a maioria dos professores se apoiam" (COSCORELLI; CAFIERO, 2002, p. 1) e que, a priori, teriam a incumbência de contribuir com o trabalho docente. No entanto, esse material acaba por ocupar mais espaço do que deveria e estabelece as bases metodológicas do trabalho de produção de leitura em sala de aula. Essa afirmação é sustentada por Coracini (1999, p. 34), quando a autora afirma que "[ [...] o livro didático constitui o centro do processo ensino-aprendizagem em todos os graus de ensino, com ênfase no ensino fundamental e médio".

A partir dessa discussão acerca da leitura, pensada pelo viés da Análise do Discurso, apresentamos uma proposta de reflexão sobre as práticas de leitura do texto publicitário promovidas pelo livro didático utilizado em uma turma de primeiro ano do Ensino Médio e as sugestões de leitura orientadas pela Proposta Curricular de Santa Catarina (1998), doravante PC-SC, material que norteia o trabalho docente, a fim de verificar a consonância entre o que apregoa a PC-SC e o que pratica, de fato, o livro didático no que tange à leitura. 


\section{O TERRITÓRIO DA ANÁLISE DO DISCURSO}

A Análise do Discurso de filiação francesa tem sua proposição em Michel Pêcheux e propõe um espaço de entremeio entre a língua e a fala, que é o discurso. Esse novo território abre um campo de questões que deslocam alguns conceitos de língua, historicidade e sujeito que foram deixados às margens pelas correntes teóricas da época. Dessa forma a AD

Interroga a Linguística pela historicidade que ela deixa de lado, questiona o Materialismo perguntando pelo simbólico e se demarca da Psicanálise pelo modo, considerando a historicidade, trabalha a ideologia como materialmente relacionada ao inconsciente sem ser absorvida por ele.

(ORLANDI, 2005, p. 20).

A Análise do Discurso coloca em questão a articulação entre o biológico e o social, ela " $[\ldots]$ se forma no lugar em que a linguagem tem de ser referida necessariamente à sua exterioridade, para que se apreenda seu funcionamento, enquanto processo significativo". (ORLANDI, 2004, p. 24).

A linguagem, do ponto de vista discursivo, passa a ser considerada como um processo de interação social e é por meio dela que o homem consegue significar o mundo que o cerca. Pêcheux (1983) propõe um estudo da linguagem colocando os princípios teóricos em espaços que podem parecer contraditórios a fim de compreender seu objeto teórico, o discurso. Este, segundo autor, é estrutura e acontecimento, uma vez que sua existência está na relação com a história e, em sua funcionalidade, é um lugar, como aponta Brandão (1994), de confronto ideológico, haja vista sua relação intrínseca com o contexto sócio-histórico e ideológico, com as condições de produção.

A seguir, elencamos alguns conceitos-chave da Análise do Discurso que consideramos importantes para pensar na nossa proposta de trabalho que tem o texto publicitário como objeto de leitura e análise:

a) Discurso: o objeto de estudo da Análise do Discurso é o discurso, entendido não como um dado empírico, mas materialidade da ideologia e que, por isso mesmo, coloca o linguístico em articulação com a História. A noção de discurso como sinônimo de frase, de informação, de mensagem, de texto não corresponde ao conceito de discurso proposto pela $\mathrm{AD}$ que apreende esse objeto [o discurso] como processo, levando em consideração as condições de sua produção, uma vez que ele é determinado por uma exterioridade sócio-histórica-cultural. O discurso, segundo Orlandi (2005, p. 21), pode ser entendido como " [...] efeito de sentidos entre interlocutores", ou seja, é um "[ [...] processo constitutivo da atividade comunicativa produtora de efeitos de sentidos, os quais são determinados por uma exterioridade sócio-históricoideológica.". (DA SILVA FILHO, 2007, p. 8). Todo discurso é determinado pelo interdiscurso, ou seja, o que o sujeito diz é determinado por outros dizeres [memória discursiva]. Dessa forma, o discurso se movimenta e se altera por conta das transformações sociais e históricas.

b) Sujeito: a noção de sujeito, que é defendida pela $\mathrm{AD}$, é de um sujeito inscrito na história; ele não enuncia na sua individualidade, mas é interpelado pela ideologia e pelo inconsciente. A constituição do sujeito discursivo está imbricada à constituição do sentido, ou seja, "[...] sujeito e sentido se constituem ao mesmo tempo, na articulação da língua com a história, em que entram o imaginário e a ideologia”. (ORLANDI, 2001, p. 99).

A AD concebe o sujeito como heterogêneo, que pode ocupar o papel de diferentes sujeitos, é um eu pluralizado, haja vista que se constitui na interação verbal. Ele acredita na evidência e na unidade do seu dizer, uma vez que é assujeitado pela ideologia e afetado pelo inconsciente. Pêcheux (1997) afirma que o sujeito é dotado de dois esquecimentos. O esquecimento $\mathrm{n}^{\circ} 1$ [esquecimento ideológico] consiste na ilusão de que ele [o sujeito] é a fonte de seu dizer. Trata-se, porém, de uma ilusão necessária e inconsciente que é constitutiva do sujeito e é caracterizada pelo "fato de que ele produz linguagem e também está reproduzido nela, acreditando ser a fonte exclusiva do seu discurso, quando, na verdade, o seu dizer nasce em outros discursos". (ORLANDI, 1983, p. 158). No esquecimento $\mathrm{n}^{\mathrm{o}} 2$ [esquecimento enunciativo], o sujeito tem a Forum linguistic., Florianópolis, v.12, n.1, p.527-541, jan./mar.2015. 
ilusão de que o que diz tem um único significado, ele esquece que há outros possíveis sentidos. Pêcheux (1997, p. 177) afirma que "[....] o efeito da forma-sujeito do discurso é, pois, sobretudo, o de mascarar o objeto daquilo que chamamos o esquecimento $\mathrm{n}^{\circ} 1$, pelo viés do funcionamento do esquecimento $\mathrm{n}^{\mathrm{o}} 2^{\prime}$.

c) Sentido: Pêcheux (1997, p. 161) afirma que "[...] o sentido de um enunciado se constitui nas relações que suas palavras, expressões ou proposições mantêm com outras palavras, expressões ou proposições de outra formação discursiva", ou seja, os sentidos emergem a partir das diferentes posições sócio-históricas e ideológicas ocupadas pelos sujeitos no processo discursivo.

É inconcebível para a $\mathrm{AD}$ a existência de um núcleo de significância inerente à palavra, uma vez que a linguagem é polissêmica e heteróclita. Nessa perspectiva, a AD se opõe à ideia saussureana da relação entre significado e significante, ou seja, de encontrar na palavra um sentido já-lá, haja vista que a constituição deste é socialmente construída. "A multiplicidade de sentido é inerente à linguagem.” (ORLANDI, 1993, p. 20).

No entanto, o sentido não pode ser qualquer um; nessa direção, para a análise do discurso, destaca Possenti (2001, p. 53), os sentidos têm um caráter necessariamente histórico. "É apenas em uma relação parafrástica empiricamente constatada que um efeito de sentido se dá”.

d) Leitura: a leitura, sob a ótica discursiva, é uma questão de historicidade, não é um "tudo ou nada." (ORLANDI, 1993, p. 9). A “interação do leitor com o tex to" é questionada pela AD, uma vez que a leitura é o embate, o confronto do leitor virtual com o leitor real. $\mathrm{O}$ autor, no momento em que escreve, imagina um leitor para quem ele dirige o texto, no entanto, no momento da leitura, há ali o leitor real que tanto pode ser um "cúmplice" do autor como pode ser um "adversário" dele. Dito de outro modo, o autor, ao elaborar o tex to instaura o seu leitor, com quem estabelece um diálogo. Essa imagem de leitor é, portanto, construída pelo autor e não equivale ao leitor real, aquele que visualiza, que lê, a presença física que "consome" o texto. Orlandi (1993, p. 9) explica que:

\begin{abstract}
Se se deseja falar em processo de interação da leitura, eis aí um primeiro fundamento para o jogo interacional: a relação básica que instaura o processo de leitura é o jogo existente entre o leitor virtual e o leitor real. É uma relação de confronto. O que, já em si, é uma crítica aos que falam em interação do leitor com o texto. O leitor não interage com o texto (relação sujeito/objeto), mas com outro(s) sujeito(s) (leitor virtual, autor etc.). A relação sempre se dá entre homens, são relações sociais; eu acrescentaria, históricas, ainda que (ou porque) mediadas por objetos (como o texto). Ficar na 'objetalidade' do texto, no entanto, é fixar-se na mediação, absolutizando-a, perdendo a historicidade dele, digo sua significância.
\end{abstract}

Ler é, portanto, produto de uma prática histórica: social e ideológica. É enxergar o que o texto diz e o que ele não diz, pois o que não é dito também significa. Ler, segundo Coracini (2001, p. 143), "[...] pressupõe um sujeito que produz sentido, envolvendo-se, dizendo-se, significando-se, identificando-se", quebrando a barreira de opacidade das palavras.

Desse modo, leitor e leitura são indissociáveis, eles não existem isoladamente, pelo contrário, constituem-se mutuamente, são elementos essenciais nesse jogo de interlocução, jogo entre o leitor real e o leitor virtual, que é a relação básica que organiza o processo de leitura. Nessa relação " [...] os interlocutores se identificam como interlocutores e, ao fazê-lo, desencadeiam o processo de significação do texto. Portanto leitura e sentido, ou melhor, sujeitos e sentidos constituem-se num mesmo processo que se configura de formas diversas". (ZEN, 2007, p. 31). 


\section{O LIVRO DIDÁTICO: BREVE CONTEXTUALIZAÇÃO ${ }^{1}$}

A Igreja, até o Renascimento, mantinha o poder absoluto sobre os povos, sobre a escrita e sobre a propagação de conhecimento. O ensino era de competência da Igreja, as escolas eram adjacentes às catedrais, aos mosteiros e a formação era destinada aos indivíduos que seguiriam a vida religiosa. Entretanto, a Igreja católica perde essa posição em detrimento das mudanças sociais, econômicas e culturais que ocorreram com a expansão marítima, o desenvolvimento do comércio, da indústria e a invenção da imprensa e, sobretudo, com a Reforma Protestante.

A Igreja católica, até então, detentora do poder, enfraquece e o Estado fica responsável pelas escolas; nesse contexto, surgem as primeiras cartilhas, material destinado à alfabetização. No entanto, o conteúdo delas era sempre voltado à religiosidade, já que era imprescindível ler as escrituras sagradas. Observa-se que essa era uma forma de a Igreja católica, mesmo com a Reforma Protestante, “[...] manipular seus fiéis, já que havia uma batalha entre a elite que tinha o desejo do lucro sem a censura explícita, e a Igreja Católica que atrapalhava o crescimento do capitalismo." (BAIRRO, 2009, p. 3).

Todos os manuais escolares até o século XVII, mesmo com a Reforma Protestante, eram voltados aos ensinamentos cristãos. […] Para a Igreja Católica, a educação deveria ser voltada para a formação do bom cristão, que em síntese seria aquele que serve a Igreja sem questionar e se cometer um 'pecado', com o pagamento das indulgências, estaria perdoado. Esse educar só atingia aqueles mais abastados, com maiores possibilidades financeiras. (BAIRRO, 2009, p. 5-6)

Em Portugal, muitas cartilhas foram escritas e muitos de seus métodos falharam até que João de Deus escreveu a Cartilha Maternal, cujo foco era a leitura. Essa cartilha foi um sucesso tão grande em Portugal que o país, além de propagar em suas escolas, também fez chegar às colônias, incluindo aí o Brasil. No entanto, esses livros eram destinados somente à elite porque o método de João de Deus objetivava formar cidadãos alfabetizados, de maneira rápida e eficaz, por meio de escolas privadas, desvinculando-se do governo. A Cartilha Maternal foi o primeiro material de alfabetização no Brasil que se diferenciava das "cartilhas de aprender", utilizadas pelos jesuítas.

$\mathrm{Na}$ época do Império, quando o ensino sofreu expansão, o material pedagógico começou a ser produzido de modo a organizar os conteúdos das aulas. Esses volumes foram o embrião do que hoje chamamos livro didático. Mais tarde, os conteúdos dos livros foram distribuídos de acordo com a faixa etária dos alunos e o material passa a sistematizar os saberes de acordo com o currículo escolar. O livro didático ganha força e conquista um lugar de destaque na sala de aula, não somente na alfabetização, mas em todos os níveis da educação.

O livro didático, ao longo do tempo, consubstanciou-se como constitutivo da prática pedagógica, ganhando espaço no ambiente escolar em uma proporção hiperbólica. O material didático ganha autoridade e legitimação nas salas de aulas e o professor " [...] autorizado pela instituição escolar (já que é portador de um diploma legalmente reconhecido), legitima o material comercializado, considerando-o como base para o seu trabalho em sala de aula." (CORACINI, 1999, p. 33). É inegável a contribuição do livro didático como instrumento de trabalho para o professor, entretanto, a sua utilização como ferramenta única para nortear as atividades de aprendizagem torna-se preocupante, como salienta a Proposta Curricular, pois o livro didático "[...] tem sido tomado $[\ldots .$.$] como a tábua de salvação em meio ao caos que se tornou o conjunto de$ tarefas educacionais […]" (PC-SC, 1998, p. 69).

A questão que colocamos aqui não é a de invalidar o livro didático em análise, mas a de chamar a atenção, já que o material diverge em muitos pontos das concepções de ensino e aprendizagem de leitura defendidas pela Proposta Curricular de Santa Catarina. Entendemos que, se bem utilizado, ele pode contribuir para a construção do conhecimento, desde que sejam observadas as particularidades resultantes da imbricação material na formulação do guia e que o professor o utilize com bom senso e tenha consciência de que ele é apenas um dos instrumentos de trabalho, não o único.

${ }^{1}$ Esta seção se destina a uma apresentação sucinta acerca da história do livro didático, uma vez que não é este o foco deste estudo.

Forum linguistic., Florianópolis, v.12, n.1, p.527-541, jan./mar.2015. 


\section{PROPOSTA CURRICULAR DE SANTA CATARINA - AS IDEIAS DE VYGOTSKY E BAKHTIN}

Desde 1988, a Rede Pública de Ensino de Santa Catarina apresenta uma proposta curricular para todo o sistema estadual de educação. Essa proposta surgiu de um complexo movimento de discussão e marca a história da educação no estado.

A Proposta Curricular de Santa Catarina como “[...] qualquer proposta curricular fundamenta-se, explícita ou implicitamente, em alguns eixos fundamentais. É impensável uma proposta curricular que se dê no espontaneísmo, sem que haja um norte a partir do qual a mesma se fundamente”. (PC-SC, 1998, p. 9). O documento aponta para o homem como ser histórico e social e opta pela concepção histórico-cultural de aprendizagem que também pode ser chamada de sócio-histórica ou sociointeracionista. Ela está embasada nas concepções de Vygotsky, que funda uma nova psicologia com base na filosofia do materialismo histórico e de Bakhtin que, concomitantemente, tenta construir uma filosofia da linguagem, cuja perspectiva sociológica subordina a psicológica.

Vygotsky (1998) propõe a linguagem como ferramenta psicológica estruturante e de ação social. Bakhtin (1988), por sua vez, lança, no mesmo contexto histórico, as bases de uma moderna concepção de linguagem que é vista como instrumento² de interlocução humana, ou seja, de interação verbal. Vygotsky e Bakhtin rompem com o antigo paradigma baseado em uma psicologia descontextualizada que ignorava a relação do sujeito com o meio em que vive. É a partir deles, portanto, que o indivíduo é visto como ser histórico. Dessa forma, há uma redefinição no campo da psicologia da educação.

Vygotsky (1998) assegura que é preciso partir do social para chegar ao individual. O homem, segundo ele, é um ser social formado dentro de um ambiente cultural historicamente definido e a formação acontece na relação dialética entre o sujeito e o meio em que vive. A Proposta Curricular de Santa Catarina intenta seguir esse propósito fundamental da teoria de Vygotsky, ancorada na grande preocupação do autor que "[...] era buscar um enfoque adequado para abordar as funções psicológicas complexas: memória voluntária, imaginação criativa e solução de problemas abstratos.” (PC-SC, 1998, p. 55).

Bakhtin (1988), na mesma direção de Vygotsky, defende a relação do sujeito com o conhecimento, construído histórico e socialmente.

Desse modo, Bakhtin elaborou uma teoria da consciência fundamentada nos aspectos sociológicos; o autor afirma que "[ [...] não basta ao homem um nascimento físico, sendo-lhe necessário um segundo nascimento, o social." (FREITAS, 2001, p. 171). Dessa forma, o nascimento concreto do homem se daria em seu meio social. Bakhtin projeta o homem para a posição de sujeito histórico e, com isso também historiciza a linguagem.

Para observar o fenômeno da linguagem, é preciso situar os sujeitos - emissor e receptor do som - bem como o próprio som, no meio social [...] a unicidade do meio social e a do contexto social imediato são condições absolutamente indispensáveis para que o complexo físico-psíquico-fisiológico [...] possa ser vinculado à língua e à fala, possa tornar-se um fato de linguagem. (BAKHTIN, 1988, p. 70-71)

A língua, segundo Bakhtin (1988, p. 109), “[...] não é constituída por um sistema abstrato de formas linguísticas […] mas pelo fenômeno social da interação verbal, realizada através da enunciação e das enunciações.". É desse modo que a PC-SC (1998, p. 61) compreende a enunciação como "[...] parte (ou recorte) de um diálogo ininterrupto no processo de interação verbal” entre os indivíduos e é determinada pelas relações sociais. Aí entra o papel da ideologia que, grosso modo, é a forma de representação do real, um espaço de contradição.

Furlanetto (2008, p. 27) destaca em Bakhtin a proposta de trabalho com os gêneros discursivos que “[...] englobam desde as formulações mais simples da vida cotidiana (tais como o bilhete, a conversa informal, o aviso, o convite), até aqueles intelectualmente mais elaborados (o artigo científico, o sermão, a lei, o

\footnotetext{
${ }^{2} \mathrm{O}$ termo "instrumento" está sendo tomado no sentido vygotskyano. Vygotsky propõe dois tipos de elementos mediadores: os instrumentos e os signos, sendo que os instrumentos, ao se interpor entre o homem e o mundo, ampliam as possibilidades de transformação da natureza. São ferramentas que servem para transformar os objetos e o próprio meio. Os instrumentos até podem ser utilizados pelos animais, mas o uso que o homem faz dos instrumentos é bem mais sofisticado, ele pode guardá-lo para um uso futuro, por exemplo.
} 
romance, o ensaio)". Ou seja, a diversidade de textos, segundo a autora, é uma ótima oportunidade para trabalhar com a língua nos seus mais variados usos no cotidiano.

O texto da PC-SC, portanto, parte do pressuposto de que é necessário estabelecer uma relação entre o indivíduo e a sociedade e o indivíduo e a consciência, dentro de uma dimensão histórica. Dito de outro modo, a linha de pensamento de Vygotsky e Bakhtin converge com a concepção de homem como ser histórico e social.

\section{POR QUE O TEXTO PUBLICITÁRIO?}

De acordo com a PC-SC, o trabalho com os diversos textos circulantes na sociedade é uma excelente oportunidade de se lidar com a língua nos seus mais variados usos no dia a dia.

O texto publicitário em sala de aula representa um avanço relevante no sentido de promover uma prática de produção de leitura subscrita a outras linguagens; além disso, a abordagem de questões da atualidade, fazendo uso da linguagem mais próxima à do cotidiano, poderá torná-lo mais persuasivo à leitura, já que (re)trata uma realidade social que diz respeito diretamente aos interesses do leitor.

Conforme Debord (2003, p. 14), vivemos em uma sociedade do espetáculo, “[...] o espetáculo não é um conjunto de imagens, mas uma relação social entre pessoas, mediatizada por imagens”. A proliferação da imagem acelera os processos comunicativos e, diante disso, o professor se depara com a necessidade de uma pedagogia que concorra com todos os atrativos (im)postos pelas diversas mídias, sobretudo aquelas compostas pela intersecção das linguagens verbal e não verbal. É nesse espaço de "angústia" do professor, que o texto publicitário aparece como uma opção produtiva de leitura com os recursos retóricos e icônicos que caracterizam a linguagem publicitária. Nesse contexto e, também, em consonância com as orientações da PC-SC, o trabalho com o gênero propaganda pode proporcionar ao aluno o desenvolvimento da autonomia no processo efetivo de práticas de leitura, pensada a partir de situações de comunicação, haja vista a proeminência dos gêneros midiáticos na sociedade moderna, um texto circulante e dos mais acessíveis à população.

O texto publicitário, como uma prática social, é formulado a partir de elementos verbais e não-verbais dispostos em anúncios permeados de estratégias persuasivas imbricadas em sua materialidade, na tentativa de seduzir o leitor/consumidor. A partir do uso de uma linguagem específica, o texto publicitário propõe levar o receptor a ações como compra, adesão política, religiosa, de ideias, entre outras. Desse modo, passa a ocupar um lugar de destaque na sociedade contemporânea e assume um papel de agente transformador, tanto na conduta como na construção de valores e opiniões.

Embora o texto publicitário seja bastante corriqueiro nas mídias (TV, outdoors, revistas, jornais, Internet, entre outros), ele é ainda pouco explorado nas aulas de português, como afirma Schimieguel (2009, p. 2),

[...] devido à falta de um constructo teórico capaz de subsidiar uma análise que se ocupa não só dos processos sintático-semânticos como também dos recursos visuais e da relação entre ambos, bem como das condições de produção dos discursos e das intencionalidades subjacentes às formações discursivas presentes nesse gênero textual.

A legitimação do texto publicitário como objeto pedagógico provoca certas inquietações, já que o comum é relacioná-lo como meio de atender a interesses comerciais e que nada tem a ver com o pedagógico. Embora seja indiscutível o caráter comercial do texto publicitário, ele se encontra em um cenário dicotômico, pois no momento em que sai dos suportes convencionais e vai para o livro didático, o anúncio publicitário passa a se constituir, também, em material didatizado, possibilitando, assim, sua utilização como objeto pedagógico. Nesse sentido, observamos que o anúncio publicitário deixa de ser um gênero do discurso da "vida real" para se tornar um gênero da escola.

E como a peça publicitária faz parte da nossa realidade linguística e social e, portanto discursiva, faz-se importante que ela esteja presente no ambiente escolar como objeto de estudo. A inserção do texto publicitário, como objeto pedagógico, é fundamental na medida em que é um agente transformador e 
formador de opinião e a escola, como espaço institucionalizado do saber e uma colaboradora na formação do cidadão, tem a possibilidade de empreender o diálogo com essa produção.

\section{ANÁLISE DOS DADOS}

Para nossa análise, focamos os anúncios que seguem:

c) Cessou o ballado do povo nas ruasmetonímia Dançando quadrilhas pra lá e pra cá. (Ascenso Ferreira)

\section{A metáfora e a metonimia na publicidade}

Os recursos expressivos mais empregados na publicidade brasileira são a metáfora e a metonímia. Observe, na frase "Para quem tem o rei na barriga", do anúncio, a presença de metáfora e metonímia. A palavra rei é metafórica porque está sendo empregada no lugar da palavra bebê. A metonímia ocorre quando o anunciante estabelece relações de inclusão e de implicação com os seguintes elementos: a parte (barriga) pelo todo (mãe), o efeito (barriga) pela causa (bebê) e o continente (barriga) pelo conteúdo (bebê).

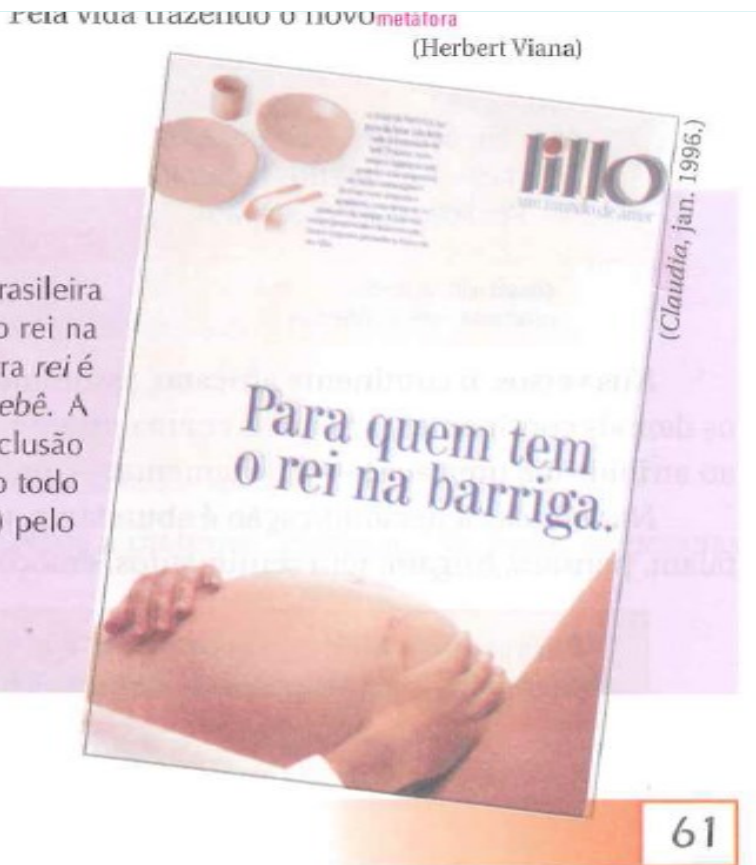

Figura 1: propaganda da Lillo

Fonte: Cereja e Magalhães (2005)

Esse anúncio publicitário aparece na unidade Língua: uso e reflexão, cujo tema é Introdução à estilística: figuras de linguagem. Trata-se de uma peça publicitária arranjada graficamente em um quadro em que se pode ler, também, informações que caracterizam o conteúdo da peça dentro de um escopo gramatical de língua portuguesa, mostrando como a produção do slogan faz uso dos recursos metafóricos e metonímicos.

Chamamos a atenção para o fato de que ao trabalhar conceitualmente as figuras de linguagem, o livro usa como exemplo outro gênero do discurso, a poesia. Notamos, portanto, que para expor metodologicamente o conteúdo, o argumento de explicação ainda pauta-se no tradicional uso do poema. Não queremos dizer com isso que não caberia o uso de poesia em sala de aula, ocorre que a poesia como mero lugar de exemplificação, de localização de conteúdo gramatical também incorre em cerceamento de sentido, podendo, inclusive, contribuir para fomentar um desprazer para a leitura do texto poético.

Observamos, também, que na edição do anúncio publicitário, extraído da revista Cláudia, de janeiro de 1996, há uma sobreposição de dois quadros. No primeiro, a imagem apresenta problemas de leitura, no que tange à visualização para decodificação da linguagem verbal, uma vez que o fragmento deslocado de seu suporte original possui uma informação que, no livro, aparece indecifrável em virtude do tamanho reduzido do anúncio. E o segundo quadro, cuja imagem está abaixo do primeiro, compõe a informação do anúncio que traz aspectos de conteúdo gramatical.

Ao visualizarmos esse enunciado no espaço enunciativo do livro, em um primeiro momento, tem-se a impressão de que ele faz parte de questões propostas como atividade a ser resolvida. No entanto, não é essa a função que o enunciado ocupa na página. Disso surge nossa questão: qual seria então a função desse 
anúncio juntamente com a explicação alocada ao seu lado? Tal questionamento é elaborado tendo em vista que esse quadro não surge concomitante à discussão do conteúdo do capítulo que trata das figuras de linguagem e, como já dito, encontra-se em sequência posterior aos exercícios de verificação de aprendizagem, sem que haja qualquer instrução que direcione o aluno a alguma atividade ou reflexão. $\mathrm{O}$ livro do professor também não orienta, não aponta caminhos para que o docente norteie um trabalho de discussão do texto. Desse modo, o que observamos é que após a execução da última questão, por parte do aluno, - questão essa anterior ao fragmento - e após a correção dos exercícios pelo professor, esse enunciado corre o risco de perder o sentido, uma vez que sua leitura não é instigada.

O conteúdo do segundo quadro visa a evidenciar ao aluno exemplos de uso da metáfora e da metonímia por meio do texto escrito: não seria possível fazer isso usando o anúncio publicitário? E, caso não fosse possível trabalhar com a imagem para explicar o conteúdo, por que colocá-la naquele espaço do livro sem que haja qualquer discussão a respeito? Temos a impressão de que o texto foi usado simplesmente como pretexto para mostrar que o livro trabalha com a diversidade de gêneros discursivos, estando assim, em consonância com a PC-SC.

As atividades que perpassam o conteúdo proposto orientam o aluno a identificar as figuras de linguagem, em frases e fragmentos completamente descontextualizados, enquanto o anúncio publicitário parece ocupar a função de um acessório que preenche um espaço vazio, no canto da página, sem que haja motivação alguma para a efetivação da prática de leitura e compreensão do texto.

Desse modo, entendemos que a proposta para o ato de ler essa peça publicitária fica comprometida, uma vez que apresenta uma análise meramente da metalinguagem, sem levar o aluno a pensar linguisticamente acerca da constituição do enunciado e muito menos a propor uma análise dos elementos de produção e dos efeitos de sentidos. 


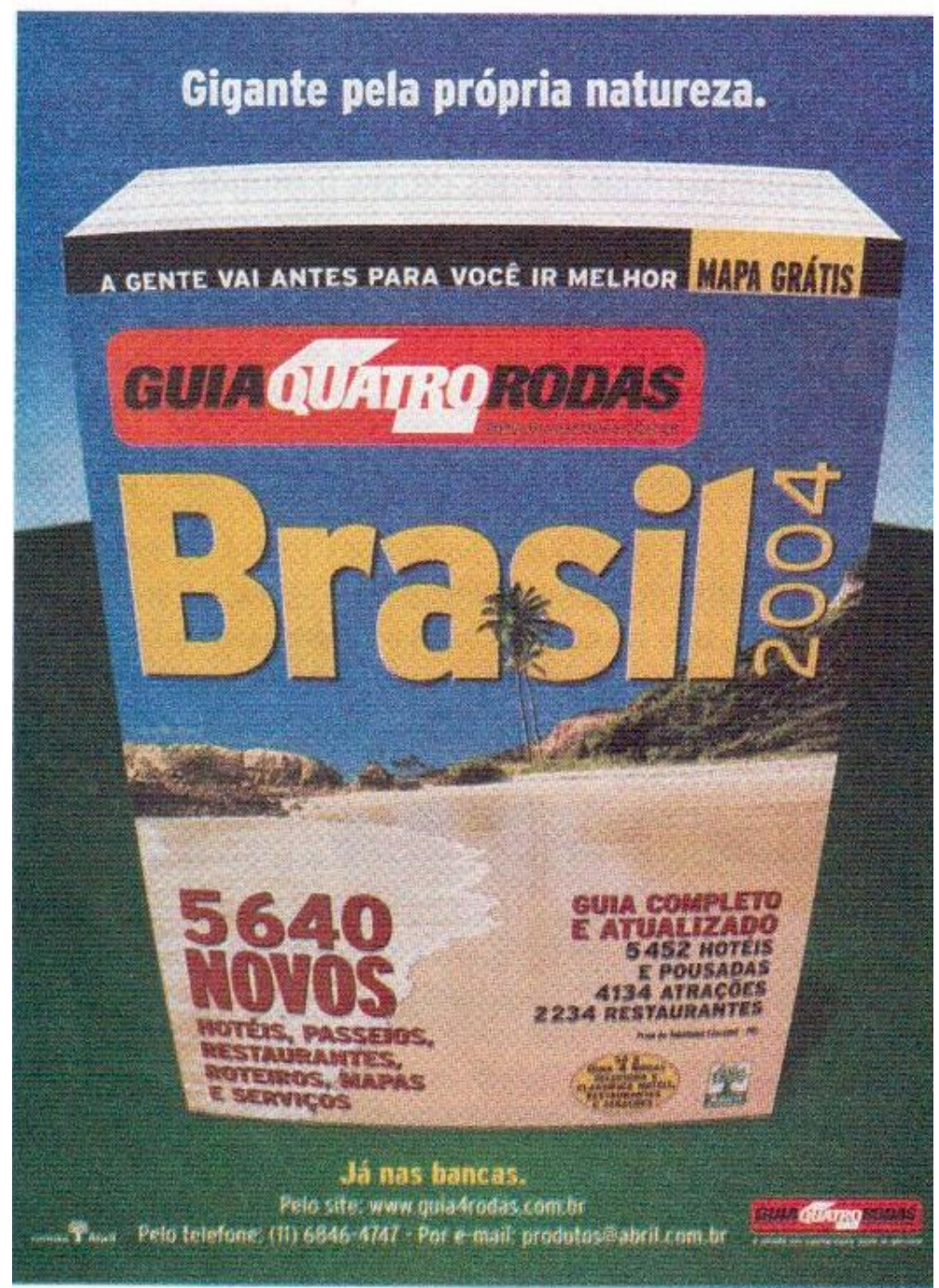

Figura 2: Guia Quatro Rodas Brasil

(Veja, 17/11/2004.

Fonte: Cereja e Magalhães (2005)

Essa peça publicitária também está localizada na unidade Língua: uso e reflexão e o tema abordado é Texto e Discurso - Intertexto e Interdiscurso. É uma unidade bastante heterogênea, haja vista que fraciona o conteúdo em: texto verbal, discurso, coesão textual, coerência textual, intertextualidade, interdiscursividade e paródia.

A estranheza está no fato de que, em momento algum, o livro usa o texto publicitário para explanar qualquer um dos conteúdos supracitados. No entanto, a seção de exercícios desse último assunto [intertextualidade, interdiscursividade e paródia] é composta unicamente por textos não verbais, quadros de pintores famosos, e textos constituídos de linguagem verbal e não verbal, a saber, anúncios publicitários. Diante disso, emergem algumas questões: por que o anúncio publicitário não aparece durante a explanação do conteúdo? Se não fosse conveniente usá-lo naquele momento, por que, então, ele surge na seção de exercícios? Ou, considerando pertinência para proposição dos exercícios, por que não foi usado como subsídio para a explicação do conteúdo? O tex to publicitário, como instrumento pedagógico, pode ser um rico material, posto ser acessível aos alunos, retratar vivências compartilhadas por eles e colocá-los diante de linguagens diversas, incitando-os a manipular textos verbais e não verbais a fim de ampliar sobremaneira a competência leitora. No entanto, há que se pensar na exploração desses textos, pelo livro didático, de modo que possam contribuir, efetivamente, com o desenvolvimento do sujeito-leitor.

Nessa perspectiva, direcionamos nosso foco à imbricação material do anúncio do Guia Quatro Rodas Brasil, extraído da revista Veja de 17 de dezembro de 2004, (Figura 2) na composição da formulação do livro didático sob análise, bem como ao processo de interpretação depreendido dessas diferentes formas de linguagem. 
Inicialmente, percebemos que, na peça publicitária, há uma sobreposição de dois quadros. No primeiro aparece o Guia Quatro Rodas Brasil, fotografado por um ângulo em que a perspectiva pela qual é enquadrado produz um efeito de grandeza física, que favorece o formato gigantesco que o anúncio pretende passar, lege de grandiosidade em termos de valor. Depois, temos a página da própria revista que também faz parte do arranjo publicitário, ou seja, a página está inserida no anúncio, é parte integrante dele. Além de participar do jogo de cores do anúncio, é nessa página que está inserida a frase "Gigantes pela própria natureza", frase que promove a ambiguidade do anúncio no jogo entre o verbal e o não verbal, que joga com o fato de o Brasil ser gigante tal como guia.

Notamos também, em um primeiro olhar, que o anúncio publicitário parece subsidiar uma proposta interessante de atividade voltada para a produção de leitura e interpretação, uma vez que não trabalha apenas com o jogo da ambiguidade produzida pela palavra, mas pelo modo como o não verbal constitui esse texto, fomentando, assim, os possíveis efeitos de sentidos que possam emergir dessa leitura. Uma leitura que, como afirma Orlandi (1993, p. 37), “[...] não encara o texto apenas como produto, mas procura observar o processo de sua produção e, logo, da sua significação. Correspondentemente, considera que o leitor não apreende meramente um sentido que está lá; o leitor atribui sentidos ao texto”.

Interessa-nos observar se a leitura, dentro dessa perspectiva, é efetivada no livro didático, uma vez que o texto publicitário, dotado de estratégias argumentativas e recursos icônicos e retóricos, faz parte de uma materialidade discursiva para além do puramente verbal e pode criar situações para que o aluno desenvolva sua competência leitora de forma ampla.

Observamos algumas questões propostas nas atividades pós-leitura desse anúncio, direcionadas pelo livro. Estas dispõem o seguinte: 1) O anúncio divulga e promove o Guia Quatro Rodas Brasil. Observe as cores do anúncio, a capa do guia
e as informações que ele veicula.

a) Que tipo de guia é esse?

b) Que relação existe entre as cores que predominam no anúncio e o objeto que ele promove?

c) Pelas informações que a capa do guia traz, é possível dizer se a cobertura do guia é ampla ou pequena? Por quê? (CEREJA; MAGALHÃES, 2005, p. 118).

De imediato, chama-nos a atenção a primeira questão (letra a) que segue após o enunciado do exercício, uma vez que se limita a uma simples pergunta de constatação, não abrindo espaço para discussões, não conduzindo o aluno a produzir sentidos.

A segunda questão (letra b) parece-nos mais interessante, na medida em que aborda a relação das cores predominantes no anúncio com o objeto que ele promove. São essas as cores que, na peça publicitária, estabelecem relação com o verbal e, como materialidade textual, têm um papel importante na leitura do anúncio publicitário. O verde e o azul da página promovem a coesão com as cores da natureza da fotografia do guia que também são coesas com as cores da bandeira do Brasil. Entretanto, observamos que o conteúdo desse capítulo, fragmentado no decorrer da explanação, aborda, entre outros temas, a intertextualidade, a interdiscursividade, a coesão textual, e esta é conceituada pelo livro como "[ [...] conexões gramaticais existentes entre palavras, orações, frases, parágrafos e partes maiores de um texto." (CEREJA; MAGALHÃES, 2005, p. 113). Isso nos leva a crer que, embora abordando temas tão pertinentes à ampliação da noção de texto, o livro didático ignorou isso, permanecendo apenas no nível do verbal, do escrito e, desse modo, o aluno não consegue perceber a coesão no nível do não verbal que está presente no anúncio por meio das cores e que poderia servir como uma materialidade textual fecunda e instigante. No entanto, essa ampliação da noção de texto não vem à tona nas discussões via livro didático. 
Diante do exposto, retomamos a noção de discurso como efeito de sentidos entre interlocutores, sendo a materialidade do discurso o texto. Assim, se for possível associar um sentido produzido em outro lugar [memória discursiva], em outra conjuntura, então, estamos diante de um texto, podendo este ser um borrão de tinta, um rabisco, uma imagem, uma pintura. Em um texto, tanto a cor, como a forma ou a palavra significam. Portanto, ele pode se manifestar em materializações diversas, não há uma configuração definida e isso justifica o inconveniente de reduzi-lo ao puramente verbal.

Diante disso, notamos uma disparidade na proposta do material didático que insere um anúncio publicitário em um contexto em que essa materialidade textual não é abordada e a questão [letra b] que poderia subsidiar um espaço de negociação, assegurando a circulação de sentidos, não dá conta dessa prática. Por outro lado, o livro do professor traz uma resposta estanque: "entre outras cores há o verde, o amarelo, o azul e o branco, cores da bandeira” (CEREJA; MAGALHÃES, 2005, p. 118). O material didático não abre um espaço para discussões acerca dos efeitos da sobreposição entre o texto verbal e o não verbal, não contempla uma produção de leitura pensada discursivamente.

Na terceira questão (letra c), o que de imediato chama nossa atenção é a ambiguidade produzida pela própria pergunta. Não sabemos se as informações a que ela se refere, são acerca da linguagem verbal ou da linguagem não verbal, uma vez que ambas as linguagens fazem parte da peça publicitária.

Na leitura, via linguagem verbal, é possível presumir que a cobertura do Guia é ampla na medida em que apresenta informações sobre os 5.640 novos hotéis, passeios, restaurantes, roteiros, mapas e serviços. Somadas às informações que o Guia já possuía, temos um total de 5.452 hotéis e pousadas, 4.134 atrações e 2.234 restaurantes. Todos esses números nos levam a pressupor a amplitude da cobertura que o Guia disponibiliza. Por outro lado, pela leitura da imagem [do não verbal], a corpulência do Guia, realçado pela dimensão hiperbólica, resultante da angulação do fotógrafo, e a espessura que ele apresenta, indicam que o Guia possui muitas páginas e, portanto, traz muitas informações, ou seja, tem uma ampla cobertura.

Diante disso, percebemos que a pergunta não leva em consideração o não verbal, visto que a resposta [fechada] que o livro do professor traz é a de que "[...] a cobertura do guia é ampla, pois menciona o número de hotéis, pousadas, restaurantes, atrações.” (CEREJA; MAGALHÃES, 2005, p. 118).

Os efeitos de sentido produzidos em ambas as leituras [verbal e não verbal], embora sejam idênticos, nesse anúncio, não abonam o livro por desconsiderar a linguagem não verbal, uma vez que, percorridos os dois caminhos, esses efeitos de sentidos poderiam ser distintos. Além disso, para formar leitores críticos é fundamental que os alunos sejam levados a manipular as variadas materialidades textuais, que sejam "[...] capazes de percorrer as tramas discursivas que levam um texto a produzir sentido. E mais, leitores que compreendam os caminhos que levam a um sentido dentro da gama de possibilidades semânticas que um texto pode abarcar." (BRAGA, 2012, p. 1). Destarte, perceber a imagem como discurso é atribuir-lhe sentido e não reduzi-la à mera descrição de seus recursos visuais.

Desse modo, somos levados à percepção de que o livro didático sob estudo limita o texto publicitário, na medida em que desconsidera o papel da imagem na construção dos sentidos que podem ser atribuídos ao texto.

\section{CONSIDERAÇÕES FINAIS}

Neste artigo, procuramos fazer um percurso investigativo acerca das proposições de práticas de leitura no livro didático. Práticas que priorizem os processos de produção de sentidos e de entendimento acerca da materialidade textual, mais especificamente, do texto publicitário, levando em conta todos os seus aspectos (verbais, não verbais, informações apresentadas ou omitidas), organizados de acordo com sua função social.

O texto publicitário pode promover uma leitura produtiva na medida em que fascina os leitores pela engenhosidade de sua construção, além de sua intensa circulação social. No entanto, o livro didático analisado, ao produzir um trabalho de leitura com a materialidade de anúncios, evidencia uma disparidade com as orientações da PC-SC, uma vez que se limita a uma leitura parafrástica. Dito de outro modo, investe na ideia de transparência, homogeneidade e completude da linguagem. Além disso, desconsidera o não verbal, parte integrante e fundamental do texto publicitário, na medida em que não amplia a noção de texto. 
A publicidade presente no livro, corpus de nossa análise, foi usada limitadamente para algumas atividades, sobretudo para exemplificar as regras gramaticais. A importância da mídia e o papel da publicidade na construção dos sentidos também foram desconsiderados.

O poder do livro didático, como discurso de verdade, enfatiza o conteúdo e “[ [...] numa relação distanciada e exterior com a linguagem reforça a manutenção do exercício escolar como um exercício de reprodução e não de formação pela linguagem”. (GRIGOLETTO, 1999, p. 75).

Diante disso, há urgência na busca por soluções aos problemas encontrados no LD no que tange à produção de leitura de textos publicitários, uma vez que essa materialidade está sendo posta objetivando o trabalho metalinguístico e desconsiderando os efeitos de produção de sentidos que possam emergir dessa leitura.

Reconhecemos que o livro didático pode ser um bom instrumento utilizado em sala de aula, mas não deve ser a única ferramenta adotada. No que tange ao tratamento dado aos gêneros do discurso das diversas esferas de comunicação humana, no caso específico do anúncio publicitário no livro analisado, a efetivação das práticas de leitura desses textos não pode ficar restrita ao trabalho metalinguístico, desconsiderando os efeitos de produção de sentidos que possam emergir dessa leitura.

\section{REFERÊNCIAS}

BAIRRO, Catiane Colaço de. Livro didático: um olhar nas entrelinhas de sua história. In: VIII SEMINÁRIO NACIONAL DE ESTUDOS E PESQUISAS: HISTÓRIA, SOCIEDADE E EDUCAÇÃO NO BRASIL, 8., 2009, Campinas. Anais Eletrônicos... Campinas: UNICAMP, 2009. p. 1-19. Disponível em: $<$ http://www.histedbr.fe.unicamp.br/acer_histedbr/seminario/seminario8/trabalhos.html>. Acesso em: 25 jul. 2012.

BAKHTIN, M. Marxismo e filosofia da linguagem. 2. ed. São Paulo: Hucitec; Petrópolis: Vozes, 1988.

BRAGA, Sandro. Leitura fílmica: uma análise discursiva dos efeitos de sentido de temas abordados em filmes da Turma da Mônica. In: SEMINÁRIO DE LITERATURA INFANTIL E JUVENIL DE SANTA CATARINA, 5., 2012, Florianópolis. Anais... Florianópolis: UFSC; UNISUL, 2012. p. 460-469. Disponível em: <https://literaturainfantilejuvenil.files.wordpress.com/2012/12/anais-5_slij_2012.pdf >. Acesso em: 10 jul. 2014.

BRANDÃO, Helena H. Nagamine. Introdução à análise do discurso. 3. ed. Campinas: Editora Unicamp, 1994.

CEREJA, William Roberto; MAGALHÃES, Thereza Cochar. Português Linguagens. 5 ed. São Paulo, 2005.

CORACINI, Maria José (Org.). O processo de legitimação do livro didático na escola de ensino fundamental e médio: uma questão de ética. In: Interpretação, autoria e legitimação do livro didático: língua materna e língua estrangeira. Campinas: Pontes, 1999, p. 33- 43.

CORACINI, Maria José. Heterogeneidade e leitura na sala de aula de língua materna. In: CORACINI, Maria José; PEREIRA, Aracy Ernst. (Org.). Discurso e sociedade: práticas em análise do discurso. Pelotas: ALB/EDUCAT. 2001, p. 137-135.

COSCARELLI, Carla V.; CAFIERO, Delaine. Análise do discurso e a sala de aula: compreensão de textos. In: SIMPÓSIO INTERNACIONAL SOBRE ANÁLISE DO DISCURSO, 2., 2002, Belo Horizonte. Anais... Belo Horizonte: FALE; UFMG, CD Rom, 2002. Disponível em: < http://www.letras.ufmg.br/carlacoscarelli/publicacoes/CoscarellaCafiero.pdf>. Acesso em: 19 ago. 2012.

DA SILVA FILHO, Urbano Cavalcante. O texto publicitário em sala de aula: uma proposta de leitura e análise do seu discurso. In: CONGRESSO DE LEITURA DO BRASIL e SEMINÁRIO MÍDIA, 
EDUCAÇÃO E LEITURA DA UNICAMP, 16.;8., 2007, Campinas. Anais eletrônicos... Campinas: UNICAMP, 2007. Disponível em:

<http://alb.com.br/arquivomorto/edicoes_anteriores/anais 16/sem05pdf/sm05ss03_03.pdf > . Acesso em: 24 jul. 2012.

DEBORD, Guy. A sociedade do espetáculo. eBoksBrasil.com. 2003. Disponível em: $<$ http://www.ebooksbrasil.org/adobeebook/socespetaculo.pdf>. Acesso em: 08 de jul. de 2014.

FREITAS, Maria Teresa de Assunção. Bakhtin e a psicologia. In: FARACO, Carlos Alberto. (Org.). Diálogos com Bakhtin. Curitiba: UFPR, 2001. p. 165-187.

FURLANETTO, Maria Marta. Inovações e conflitos na Proposta Curricular de SC: perspectivas na formação de professores. Linguagem E̊ Ensino, Pelotas, v. 11, n. 2, p. 287-310, jul./dez. 2008. Disponível em: $<$ http://rle.ucpel.tche.br/php/edicoes/v1 1n2/o1MariaMarta.pdf $>$. Acesso em: 23 de jul. 2012.

GRIGOLETTO, Marisa. (Org.). Leitura e funcionamento discursivo do livro didático. In: CORACINI, Maria José. Interpretação, autoria e legitimação do livro didático. Campinas, SP: Pontes, 1999. p. 67-77.

ORLANDI, Eni P. et al. Sujeito छ̋ discurso. São Paulo: Editora da PUC-SP (Série Cadernos PUC - 31), 1988.

ORLANDI, Eni P. A linguagem e seu funcionamento. As formas do discurso. São Paulo: Brasiliense, 1983.

Discurso e leitura. 2 ed. São Paulo: Cortez, 1993.

Discurso e texto: formulação e circulação dos sentidos. Campinas, SP: Pontes, 2001.

Autoria, leitura e efeitos do trabalho simbólico. Campinas: Pontes, 2004.

Análise de discurso: princípios e procedimentos. 6. ed. São Paulo: Pontes, 2005.

PÊCHEUX, M. Discurso-estrutura ou acontecimento. Trad. de Eni P. Orlandi. Campinas: Pontes, 1983.

Semântica e discurso. Uma crítica à afirmação do óbvio. Trad. de Eni Orlandi. Campinas, SP: Editora da Unicamp, 1997.

POSSENTI, S. Ainda sobre a noção de efeito de sentido. In: GREGOLIN, M. R.; BARONAS, R. (Org.).

Análise do Discurso: as materialidades do sentido. São Carlos: Claraluz, 2001. p. 45-59.

SANTA CATARINA. Secretaria de Estado da Educação e do Desporto. Proposta Curricular de Santa Catarina: Educação Infantil, Ensino Fundamental e Médio: disciplinas curriculares. Florianópolis: COGEN, 1998.

SCHIMIEGUEL, Otávio. O texto publicitário na sala de aula: uma proposta de análise. Curitiba: SEED, 2009. Disponível em: <http://www.diaadiaeducacao.pr.gov.br/portals/pde/arquivos/392-4.pdf>. Acesso em: 20 jul. 2012.

VIGOTSKY, Lev Semënovič. A formação social da mente. São Paulo: Martins Fontes, 1998.

ZEN, Tânia Maria Campos. A construção do sujeito-leitor na crônica fotográfica. Campinas, SP: [s.n.], 2007. Disponível em: <http://www.bibliotecadigital.unicamp.br/document/?code=vtls000428334\&fd=y >. Acesso em: 25 jul. 2012. 
Recebido em 15/og/go14. Aprovado em 13/02/15. 